\title{
Development of Coloured Stoneware Bodies through the Incorporation of Industrial $\mathrm{Cr} / \mathrm{Ni}$ Electroplating Sludge
}

\author{
Inês Silveirinha Vilarinho ${ }^{1, *(\mathbb{C})}$, Jorge Carneiro ${ }^{2}$, Carlos Pinto ${ }^{2}$, João António Labrincha ${ }^{1}(\mathbb{D}$ \\ and Maria Paula Seabra ${ }^{1, * \mathbb{D}}$ \\ 1 CICECO_Aveiro Institute of Materials, Department of Materials and Ceramic Engineering, \\ University of Aveiro, 3810-193 Aveiro, Portugal; jal@ua.pt \\ 2 Grestel-Produtos Cerâmicos S.A, Zona Industrial de Vagos-Lote 78, 3840-385 Vagos, Portugal; \\ jorgecarneiro@grestel.pt (J.C.); carlospinto@grestel.pt (C.P.) \\ * Correspondence: inessvilarinho@ua.pt (I.S.V.); pseabra@ua.pt (M.P.S.)
}

Citation: Vilarinho, I.S.; Carneiro, J.; Pinto, C.; Labrincha, J.A.; Seabra, M.P. Development of Coloured Stoneware Bodies through the Incorporation of Industrial $\mathrm{Cr} / \mathrm{Ni}$ Electroplating Sludge. Sustainability 2021, 13, 1999. https://doi.org/10.3390/su13041999

Academic Editor: Elena Rada

Received: 19 January 2021

Accepted: 9 February 2021

Published: 12 February 2021

Publisher's Note: MDPI stays neutral with regard to jurisdictional claims in published maps and institutional affiliations.

Copyright: (c) 2021 by the authors. Licensee MDPI, Basel, Switzerland. This article is an open access article distributed under the terms and conditions of the Creative Commons Attribution (CC BY) license (https:// creativecommons.org/licenses/by/ $4.0 /)$.

\begin{abstract}
Electroplating sludge (ES) is currently disposed in landfills and, because of its heavy metal content, poses serious threats to the environment and human health. However, ES might have potential use as colouring agent due to its high concentration of chromium and nickel. Thus, the present work aims at studying the effect of ES incorporation into stoneware bodies. The influence on the final characteristics of fired samples, ES amount and pre-treatment were analysed. It was found that stoneware pastes having uniform brownish hues can be obtained with only $3 \mathrm{wt} . \%$ of sieved $(<212 \mu \mathrm{m})$ ES. The obtained specimens have, once fired, the desired technical and aesthetical characteristics. Further, leaching tests confirmed the immobilisation of hazardous ES species in the ceramic matrix. Hence, it can be concluded that this waste can be used as colouring agent of stoneware pastes substituting commercial pigments and contributing to more sustainable consumption and production in the ceramic sector.
\end{abstract}

Keywords: hazardous waste management; stoneware paste; industrial electroplating sludge; waste valorisation; circular economy

\section{Introduction}

The $\mathrm{Cr} / \mathrm{Ni}$ electroplating sludge (ES), produced from the galvanizing of metallic surfaces to avoid corrosion, contains a relatively high amount of heavy metals (such as nickel, copper and chromium), soluble salts (chlorides and sulphates), pathogenic microorganisms and organic pollutants [1]. Thus, this $\mathrm{Cr} / \mathrm{Ni}$ sludge has a serious biological toxicity and can be a threat to human health. ES is classified as hazardous waste by environmental agencies (e.g., European Union Commission Decision 2001/573/EC) and according to the European Waste Catalogue it belongs to the family CER 1902 [2]. Currently, this hazardous waste is being disposed in landfills as a means of immobilising its heavy metal content. According to US Environmental Protection Agency (EPA), an estimated 1.3 million tons of wet electroplating sludge are generated per year, requiring proper disposal in landfills for hazardous wastes or immobilisation treatments [3]. In 2018, the amount of ES generated in the European Union (EU27) was around 150,000 tons [4]. The inertisation of the hazardous species of the ES in other processes/products might be a solution for avoiding the high costs associated with landfilling $[1,5,6]$. In this regard, the scientific community has been working on industrial waste valorisation to make processes more sustainable and efficient in relation to both economic and environmental aspects and contribute, in this way, to the circular economy.

Ceramic products are a suitable route for the recycling of different types of waste since the compositions and the firing cycles can be adjusted to the requirements of each product facilitating the incorporation of the different compounds [7]. Therefore, the addition of industrial wastes in the ceramic sector has been widely studied [8-12]. In structural and 
vitrified ceramic products, a wide variety of waste products/secondary raw materials have been studied, such as municipal waste [13], waste from water treatment $[14,15]$, galvanization sludge $[16,17]$, aluminium sludge waste $[18,19]$, glass waste $[20,21]$, fine steel sludge [22] and red mud [23,24]. In more detail, the possible use of municipal sewage sludge in the production of ceramic floor tiles was studied [11]. It was concluded that an addition of $7 \mathrm{wt} . \%$ of this sludge to the standard formulation originates, after being fired at $1150{ }^{\circ} \mathrm{C}$, a material with properties compatible with the ISO standards for this category of ceramic tiles (water absorption $<10 \%$ ). Low temperature stoneware tiles incorporating boron-rich waste glass were also investigated [7]. With this secondary raw material, a reduction of $140^{\circ} \mathrm{C}$ in the firing temperature was achieved without compromising the properties of the tiles. The use of discarded sanitaryware waste as a raw material in sanitaryware production was also explored [25]. This residue aimed to substitute feldspar in the ceramic composition and in all tested compositions (substitution, in weight, from $5 \%$ to $100 \%$ of the feldspar) no significant deviations from the control formulation were observed for density, linear shrinkage and water absorption values. The flexural strength exhibited a decrease with the waste content increase; however, all the formulations presented values were above the minimum required for sanitary ware, $20.4 \mathrm{kgf} / \mathrm{cm}^{2}$. Therefore, it was concluded that this discarded sanitaryware waste could be recycled. In addition, the influence of using electronic waste, namely cathode ray tube glass, in the production of transparent ceramic frits was evaluated [26]. It was observed that the material incorporating $25 \mathrm{wt} . \%$ of this waste exhibits adequate properties (e.g., chemical resistance, thermal shock resistance, staining resistance, Mohs hardness, surface abrasion resistance and crazing resistance) according to the ISO 10545 and can, thus, be used.

Concerning the use of electroplating sludge (ES) in the ceramic sector, some studies have been performed on the preparation of inorganic pigments [27] and in ceramic bodies, tiles and bricks, [28-30]. However, no work involving the integration of this waste in tableware and decorative ceramic products was found, revealing the existence of opportunities for differentiation and innovation.

The global tableware market size was valued at EUR 37.1 billion (USD 40.1 billion) in 2018 and is expected to expand at a compound annual growth rate (CAGR) of $6.0 \%$ [31]. Nowadays, an increasing demand for textured surfaces and colour patterns to reach aesthetic and visual diversity is observed [31]. In addition, the European Commission developed the European Green Deal, which aims to boost the efficient use of resources by moving to a circular economy, restoring biodiversity and cutting pollution [32]. Consequently, ecofriendly products have also been increasingly required [33] placing the integration of industrial wastes as colouring agents in line with this trend. The environmental advantages of using hazardous wastes in ceramic bodies' composition start with the avoidance of disposal, with the immobilisation of dangerous species also expectable upon the thermal treatment if processing conditions are simultaneously controlled. Costs reduction is favoured by minimizing the required amount of commercial pigments, since they are partially substituted by the waste. Actually, the ES has no commercial value and represents a cost for the companies due to the high landfilling fees, therefore its cost would be lower than that of commercial virgin raw materials [27]. Moreover, the use of a coloured paste simplifies the production process of the ceramic pieces given that the various aesthetic effects result from surface reliefs of the ceramic piece. In this case, the same enamel can be used, reducing its waste and the time spent to change it.

This work studied the incorporation of ES as colouring agent of stoneware bodies. Different ES proportions ( 1 and $3 \mathrm{wt} . \%$ ) and pre-treatments after drying were tested: (I) disaggregation + sieving at $425 \mu \mathrm{m}$, (II) milling + sieving at $212 \mu \mathrm{m}$, (III) $=$ (II) + calcination. Lab-scale specimens were produced and characterised, but the proof of concept was obtained in a pilot scale trial involving the production of cups. Leaching tests were performed to check its effectiveness at immobilizing the hazardous species. 


\section{Materials and Methods}

\subsection{Materials}

A typical stoneware ceramic suspension provided by Grestel-Produtos Cerâmicos S.A. was used for the incorporation of $\mathrm{Cr} / \mathrm{Ni}$-rich electroplating sludge (ES) generated by Grohe Portugal-Componentes Sanitários, Lda. Dolapix was the commercial deflocculant added to adjust the viscosity of the slurry. For the leaching experiments, glacial acetic acid, from Fisher Chemical, was used.

\subsection{Samples Preparation}

Two distinct incorporation levels (1 and 3 wt.\%) of ES were tested. The sludge was dried at $105^{\circ} \mathrm{C}$ and, afterwards, was subjected to three different pre-treatments:

1. Manual disaggregation in an agate mortar followed by sieving at $425 \mu \mathrm{m}$;

2. Milling with zirconia balls during $10 \mathrm{~min}$ (proportion of 1:4, ES:balls) followed by sieving at $212 \mu \mathrm{m}$;

3. Milling and sieving at $212 \mu \mathrm{m}$ (as in II) + calcination at $600{ }^{\circ} \mathrm{C}$ (heating rate of $10{ }^{\circ} \mathrm{C} / \mathrm{min}$ and a dwell time of $30 \mathrm{~min}$ ).

ES collected in two distinct periods were used: Lot A (collected in 2018) and Lot B (collected in 2019). Table 1 presents the tested formulations. The numbers reveal the added ES amounts (1 and $3 \mathrm{wt} . \%$ ) and the letters detail the applied pre-treatment (s-sieved at $212 \mu \mathrm{m}$ and $\mathrm{c}$ - calcined at $600^{\circ} \mathrm{C}$ ). In ES1 and ES3 the sludge was simply disaggregated and sieved at $425 \mu \mathrm{m}$ (pre-treatment I), in ES3s the sludge was milled and sieved at $212 \mu \mathrm{m}$ (pre-treatment II) and in ES1sc and ES3sc was milled, sieved at $212 \mu \mathrm{m}$ and calcined (pretreatment III). The sludge from Lot A was used in all tests, while the one collected in 2019 (Lot B) was only tested with the highest concentration, $3 \mathrm{wt} \%$.

Table 1. Stoneware paste tested compositions ${ }^{(a)}$.

\begin{tabular}{ccccccc}
\hline & ES0 & ES1 & ES3 & ES3s & ES1sc & ES3sc \\
\hline & \multicolumn{7}{c}{ wt. (\%) } \\
\hline Stoneware paste & 100 & 99 & 97 & 97 & 99 & 97 \\
ES (pre-treatment I) & - & 1 & 3 & - & - & - \\
ES (pre-treatment II) & - & - & - & - & 1 & 3 \\
ES (pre-treatment III) & - & - & - & - & - \\
\hline
\end{tabular}

(a) ES amount taking into account the loss on ignition (LOI) and moisture values.

The formulated suspensions were homogenised in a turbo diluter adding water and Dolapix amounts to reach density and viscosity values of $\approx 1720 \mathrm{~g} / \mathrm{cm}^{3}$ and $\approx 30 \mathrm{~s}$ (Ford cup with $4 \mathrm{~mm}$ diameter), respectively, which are the values used industrially for the slip casting process.

To obtain parallelepipedic samples (of approximately $12 \times 2 \times 1 \mathrm{~cm}^{3}$ ) the slip was sieved (at $425 \mu \mathrm{m}$ ) and then cast in gypsum moulds. The samples stayed overnight in the mould, then were removed and kept at room temperature $\left(\approx 20^{\circ} \mathrm{C}\right)$ for 1 day. Subsequently, they were dried (at $120^{\circ} \mathrm{C}$ for $12 \mathrm{~h}$ ) and fired according to the cycle shown in Figure $1 \mathrm{a}$, up to a maximum temperature of $1220^{\circ} \mathrm{C}$. The used firing cycle is similar to the one used industrially for this type of paste. 


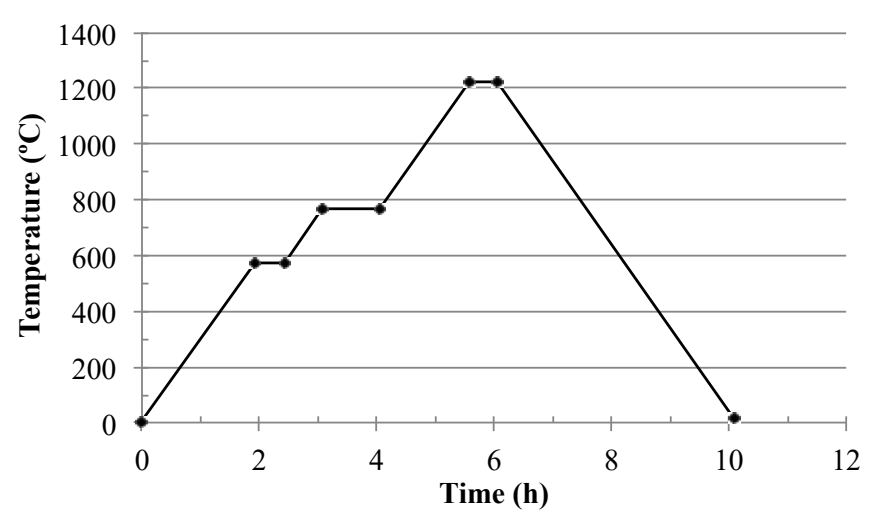

(a)

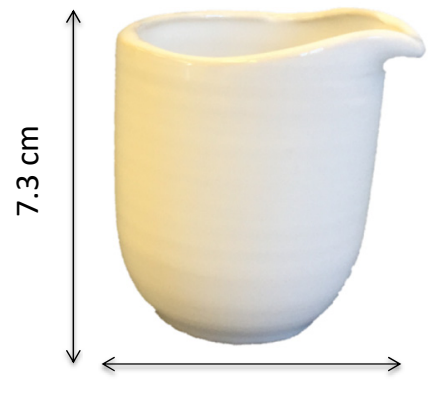

$7.2 \mathrm{~cm}$

Figure 1. (a) Firing cycle used, (b) Industrially glazed cup sample.

Additionally, for the leaching tests, cups were prepared with the compositions presented in Table 1 (an example is displayed in Figure 1b). For this purpose, to obtain the desired wall thickness, the slip stayed $30 \mathrm{~min}$ in gypsum moulds and then the extra casting slip was poured. The subsequent procedure was similar to the one followed for the parallelepipedic specimens. However, before firing (following the same cycle Figure 1a), the cups were industrially glazed with an opaque white glass.

\subsection{Characterization Techniques}

\subsubsection{Physicochemical Characteristics of the Electroplating Sludge}

The chemical composition of the electroplating sludge was obtained by X-ray fluorescence (XRF) in a Philips X'Pert PRO MPD spectrometer while the loss on ignition (LOI) at $1000{ }^{\circ} \mathrm{C}$ was also determined. Thermal analyses (DTA/TG, differential and thermogravimetric) were performed simultaneously (STA 409 EP, Netzsch equipment). The particle size distribution was obtained by laser diffraction in a Coulter LS analyser (LS 230, Fraunhofer optical model). Lastly, the moisture content of both ES and stoneware paste was determined using an AMB balance (model 310, Adam equipment).

\subsubsection{Specimens Characterization}

Characterization tests of wet (as-casted), dried and fired specimens were carried out using five replicates in each test and their respective mean value and standard deviation were calculated. The linear shrinkage of the samples upon drying (LSD), firing (LSF) and total (LST) were calculated by the difference in sample length and dividing by the initial length $(\%)$.

The fired specimens $\left(10.8 \times 1.8 \times 0.9 \mathrm{~cm}^{3}\right)$ were characterised in terms of: (i) weight loss (\%) relative to the weight of the dried specimen; (ii) apparent density $\left(\mathrm{g} / \mathrm{cm}^{3}\right)$ determined from the sample weight and size; (iii) water absorption (\%) determined by the difference of weight between the dry specimen and the specimen immersed for $2 \mathrm{~h}$ in boiling water-(according to the BS EN 1217 standard [34]) and dividing by the dry weight; (iv) three-point flexural resistance $\left(\mathrm{kgf} / \mathrm{cm}^{2}\right)$ using a universal testing machineShimadzu Autograph AG-25TA; (v) L*a*b* colour coordinates (CIELab method). A portable colourimeter-Konica Minolta Chroma Meter CR-400 was used and data were collected in five distinct zones of each sample. The CIEL*a* $b^{*}$ data are expressed as brightness $L^{*}$, changing from 0 (black) to 100 (white), $\mathrm{a}^{*}$ (+ red, - green), and $\mathrm{b}^{*}$ (+ yellow, - blue) [35]. The colour difference, $\Delta \mathrm{E}$, between the samples prepared with ES collected in 2018 (Lot A) and 2019 (Lot B), was evaluated as follows:

$$
\Delta \mathrm{E}=\left[\left(\mathrm{L}_{\text {Lot B }}-\mathrm{L}_{\text {Lot A }}\right)^{2}+\left(\mathrm{a}_{\text {Lot B }}-\mathrm{a}_{\text {Lot A }}\right)^{2}+\left(\mathrm{b}_{\text {Lot B }}-\mathrm{b}_{\text {Lot A }}\right)^{2}\right]^{0.5}
$$


where $0<\Delta \mathrm{E}<1$ means that differences in colour cannot be perceived by the standard observer; $1<\Delta \mathrm{E}<2$ only perceived by an experienced observer; $2<\Delta \mathrm{E}<3.5$ an inexperienced observer can detect differences; $3.5<\Delta \mathrm{E}<5$ everyone can see the differences [27,36]. The fracture surfaces of the specimens were carbon coated and observed by Scanning Electron Microscopy/Energy Dispersion Spectroscopy (SEM/EDS, Hitachi S-4100, 25 kV acceleration voltage, Tokyo, Japan).

\subsubsection{Leaching Experiments}

Leaching tests were carried out to determine the concentration of chromium $(\mathrm{Cr})$, nickel $(\mathrm{Ni})$, cadmium $(\mathrm{Cd})$ and lead $(\mathrm{Pb})$ removed by 4 vol.\% acetic acid solution, according to the EU Ceramic Directive 84/500/EEC [37]. For this purpose, a 4 vol.\% acetic acid solution was firstly prepared from glacial acetic acid and distilled water. Subsequently, fired cups (Figure 1b) were randomly selected. Pieces were washed with a detergent solution and then rinsed with tap water followed by distilled water. After drying, the cups were filled with the acid solution to within approximately $6 \mathrm{~mm}$ of overflowing. Finally, the cups were covered with aluminium foil, to prevent evaporation of the solution, and the acid solution stayed in the samples for $24 \mathrm{~h}$ at room temperature, $22 \pm 2{ }^{\circ} \mathrm{C}$ [37]. Afterwards, the solution was homogenised and analysed by inductively coupled plasma mass spectrometry (ICP-MS 7700 series).

\section{Results and Discussion}

\subsection{Electroplating Sludge Characterization}

The chemical composition and the loss on ignition (LOI) of the electroplating sludge (Lot A and Lot B) is shown in Table 2. The main components of Lot A are nickel, chromium, sulphur trioxide and silicon dioxide, totalizing $52.67 \mathrm{wt} . \%$. In Lot B the most abundant component is calcium oxide (16.08 wt.\%) followed by the same four components of Lot A $\left(\mathrm{Ni}, \mathrm{Cr}, \mathrm{SO}_{3}\right.$ and $\left.\mathrm{SiO}_{2}\right)$ whose total amount represents $43.6 \mathrm{wt} . \%$. The quantity of colouring species $\mathrm{Ni}$ and $\mathrm{Cr}$ in each batch is different, being lower in Lot $\mathrm{B}$ due to the diluting effect of calcium oxide: $\mathrm{Ni}=25.9$ (Lot A) and $15.5 \mathrm{wt} . \%($ Lot $\mathrm{B}) ; \mathrm{Cr}=15.3($ Lot $\mathrm{A})$ and $9.1 \mathrm{wt} . \%$ (Lot B). The LOI value of both lots is also different, being 34.3 and $22.9 \mathrm{wt} . \%$ for Lot $\mathrm{A}$ and Lot $B$, respectively.

Table 2. Average chemical composition of electroplating sludge (ES) (Lot A and Lot B).

\begin{tabular}{ccc}
\hline Component & Lot $\mathbf{A}(\mathbf{w t} . \%)$ & Lot $\mathbf{B}$ (wt.\%) \\
\hline $\mathrm{Ni}$ & 25.9 & 15.5 \\
$\mathrm{Cr}$ & 15.3 & 9.1 \\
$\mathrm{SO}_{3}$ & 5.84 & 10.5 \\
$\mathrm{SiO}_{2}$ & 5.63 & 8.5 \\
$\mathrm{P}_{2} \mathrm{O}_{5}$ & 4.45 & 2.7 \\
$\mathrm{Cu}$ & 2.23 & 5.05 \\
$\mathrm{Al}_{2} \mathrm{O}_{3}$ & 1.66 & 3.27 \\
$\mathrm{Zn}$ & 1.58 & 2.62 \\
$\mathrm{CaO}$ & 1.09 & 16.1 \\
$\mathrm{~Pb}$ & 0.88 & 0.21 \\
$\mathrm{Fe} \mathrm{O}_{3}$ & 0.65 & 1.15 \\
$\mathrm{~W}$ & 0.34 & 0.19 \\
$\mathrm{MgO}$ & 0.16 & 0.79 \\
$\mathrm{Ta}$ & 0.16 & 0.11 \\
$\mathrm{Nd}$ & 0.09 & 0.036 \\
$\mathrm{Ce}$ & 0.09 & 0.038 \\
$\mathrm{Ba}$ & 0.07 & 0.086 \\
\hline
\end{tabular}


Table 2. Cont.

\begin{tabular}{ccc}
\hline Component & Lot A (wt.\%) & Lot B (wt. \%) \\
\hline $\mathrm{K}_{2} \mathrm{O}$ & 0.07 & 0.119 \\
$\mathrm{Cl}$ & 0.06 & 0.232 \\
$\mathrm{Sn}$ & 0.06 & 0.024 \\
$\mathrm{La}$ & 0.05 & 0.645 \\
$\mathrm{TiO}_{2}$ & 0.03 & 0.174 \\
$\mathrm{Hf}$ & 0.02 & 0.028 \\
$\mathrm{Zr}$ & - & 0.025 \\
$\mathrm{~V}$ & - & 0.062 \\
$\mathrm{Co}$ & - & 0.512 \\
\hline $\mathrm{LOI}$ & 34.3 & 22.9 \\
\hline
\end{tabular}

The weight loss and heat flow curves of the electroplating sludge, Lot A, measured by DTA/TG are presented in Figure 2. The initial weight loss (TG line) observed upon heating is caused by dehydration and hydroxide decomposition, which is accompanied by an endothermic peak in DTA $\left(\approx 180^{\circ} \mathrm{C}\right)$. Between 400 and $600{ }^{\circ} \mathrm{C}$, a slight exothermic peak is observed, which is associated with the burning out of organic compounds. The ES weight seems to stabilize at $600{ }^{\circ} \mathrm{C}$; however, in order to confirm this fact, discrete firing at 600 and $800{ }^{\circ} \mathrm{C}$ (heating rate of $10^{\circ} \mathrm{C} / \mathrm{min}$ and dwell time of $30 \mathrm{~min}$ ) was conducted. At both temperatures the values of weight loss were very similar $(\approx 36$ and $\approx 24 \mathrm{wt} . \%$ for Lot $A$ and $B$, respectively). This observation guided the calcination conditions of the material for further use with the selected temperature being $600{ }^{\circ} \mathrm{C}$.

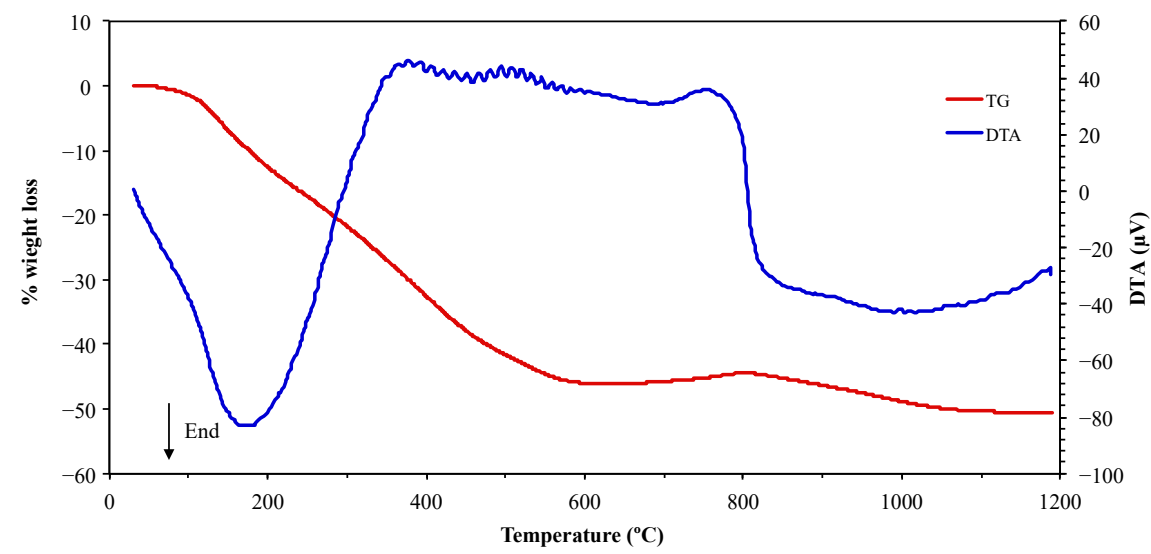

Figure 2. Electroplating sludge (Lot A) TG and DTA results.

Dried and manually disaggregated portions of ES were used to determine the particle size distribution. Particles ranging from submicrometric size $(0.5 \mu \mathrm{m})$ to $700 \mu \mathrm{m}$ were detected, denoting the presence of agglomerates. The estimated average particle size is approximately $230 \mu \mathrm{m}$ for both used ES lots. Since the hue and colouring power of the pigment is strongly affected by the particle size distribution, the control of this characteristic (e.g., by proper sieving) is advisable and thus, sieving at 425 and $212 \mu \mathrm{m}$ (pre-treatment I and II, respectively) were performed.

\subsection{Specimen Characterisation}

The fired specimens $\left(10.8 \times 1.8 \times 0.9 \mathrm{~cm}^{3}\right)$ and weight loss values are shown in Figure 3. Observing Figure 3a, it can be immediately depicted that ES sludge promotes the colouring of the ceramic paste. The obtained stoneware bodies incorporating ES show distinct brownish hues depending on the ES amount and performed pre-treatment. A rustic (nonuniform) aspect is observed in ES1 and ES3 samples, which is associated a broader particle size distribution (pre-treatment I). On the other hand, smoother colouration is observed when ES was milled + sieved at $212 \mu \mathrm{m}$. Nevertheless, a more detailed discussion 
of ES colouring characteristics will be presented below. The weight loss values of the specimens prepared with the calcined sludge (ES1sc and ES3sc) are similar to the control sample, ES0 (Figure $3 b$ ). This fact was expected since the pre-treatment applied to ES eliminates any possible weight reduction caused by dehydration and hydroxides decomposition and organic compounds. On the contrary, the addition of non calcined $\mathrm{Cr} / \mathrm{Ni}$ sludge slightly increases the weight loss of the samples. Nonetheless, all obtained values are within the industrial limits (6-7 wt.\%). Furthermore, very small differences are noticed when different ES lots are used (Figure 3b), not showing any influence of the compositional variability of the lots on the specimens' weight loss.

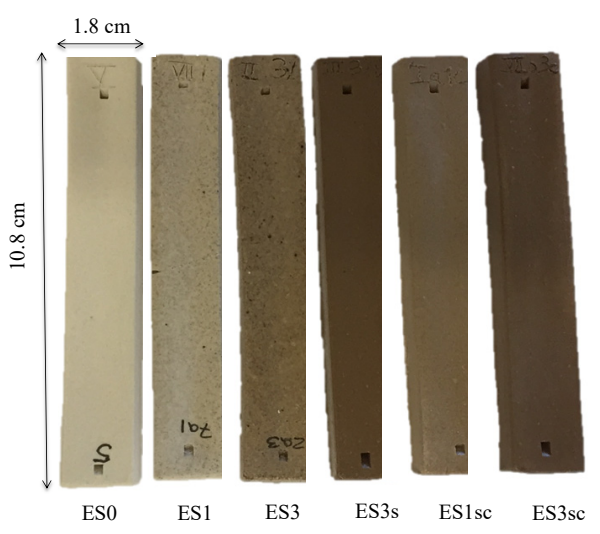

(a)

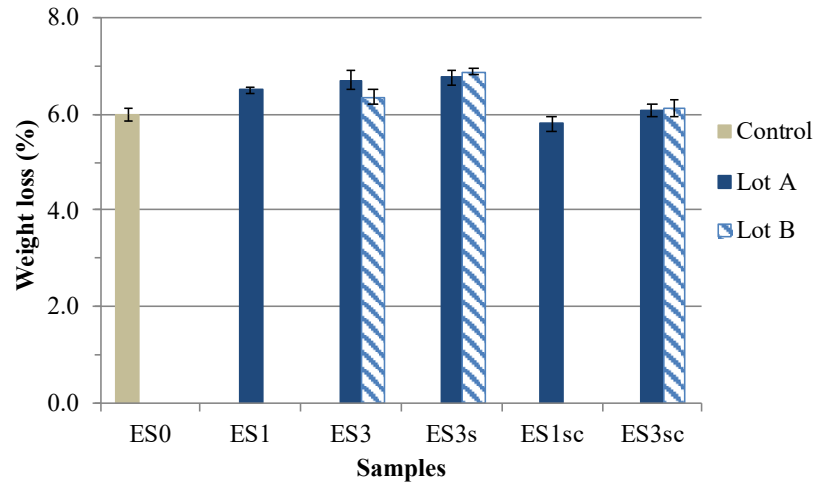

(b)

Figure 3. (a) Fired specimens; (b) Effect of the ES addition on the specimen's weight loss.

Values of the drying, firing and total shrinkage are presented in Figure 4. It was not observed a notorious influence of the addition of the residue, neither of the lot or performed pre-treatment. Moreover, all values are within the typical industrial shrinkage (drying and firing shrinkage: $6-7 \%$; total shrinkage: $9-11 \%$ ): this is expected since the incorporation level of the ES is relatively low. The values of the water absorption and the density of the fired specimens are presented in Table 3. Independently of the performed pre-treatment and batch (Lot A or B), the addition of the ES promotes a decrease in the water absorption which is due to the fluxing action of the metal-rich waste that seems to promote a higher densification degree. In line with the water absorption values, the density of the specimens exhibits a small rise for the samples containing ES; the higher values are observed for the specimens with $3 \mathrm{wt} . \%$ of ES.

Table 3. Effect of the ES addition on water absorption and density values.

\begin{tabular}{cccccccc}
\hline & & ES0 & ES1 & ES3 & ES3s & ES1sc & ES3sc \\
\hline \multirow{2}{*}{ Water absorption (\%) } & Lot A & $0.44 \pm$ & $0.21 \pm 0.001$ & $0.21 \pm 0.001$ & $0.11 \pm 0.001$ & $0.06 \pm 0.001$ & $0.0 \pm 0.001$ \\
& Lot B & 0.001 & - & $0.13 \pm 0.1$ & $0.08 \pm 0.1$ & - & $0.07 \pm 0.1$ \\
\hline Density & Lot A & \multirow{2}{*}{$2.07 \pm 0.1$} & $2.05 \pm 0.1$ & $1.96 \pm 0.1$ & $2.09 \pm 0.1$ & $2.26 \pm 0.1$ & $2.12 \pm 0.1$ \\
$\left(\mathrm{~g} / \mathrm{cm}^{3}\right)$ & Lot B & & - & $2.20 \pm 0.1$ & $2.21 \pm 0.1$ & - & $2.10 \pm 0.1$ \\
\hline
\end{tabular}




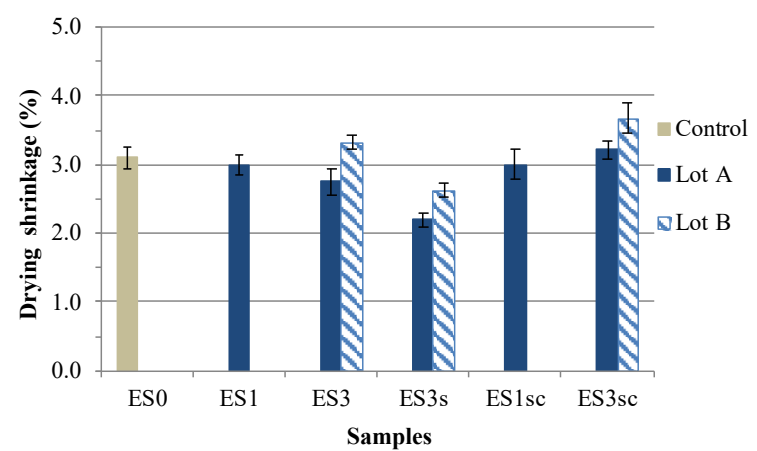

(a)

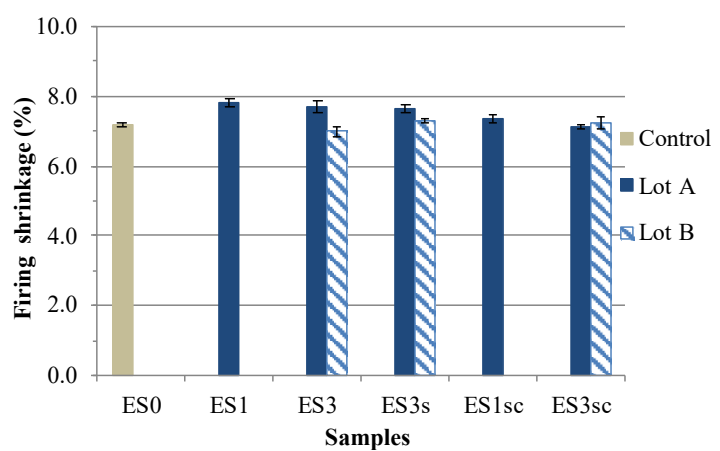

(b)

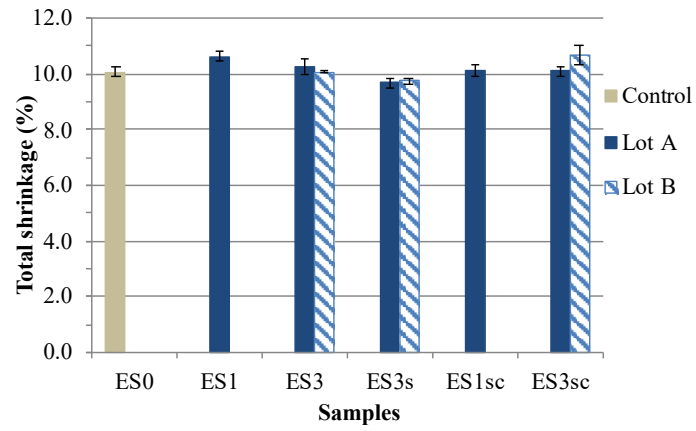

(c)

Figure 4. Effect of the addition of ES on samples' shrinkage: (a) drying, (b) firing and (c) total.

Figure 5 shows the flexural strength values of the fired samples. Furthermore, in this case, the observed increase when ES level enhances is in line with the obtained water absorption values. Samples containing calcined sludge (ES1sc and ES3sc) present maximal strength (between 400 and $495 \mathrm{kgf} / \mathrm{cm}^{2}$ ), since the decomposition reactions on the waste occurred in the pre-treatment step. These reactions might liberate gases that will create internal porosity, being responsible for the strength decrease of non calcined ES containing samples (from $388 \mathrm{kgf} / \mathrm{cm}^{2}$ to around $300 \mathrm{kgf} / \mathrm{cm}^{2}$ ).

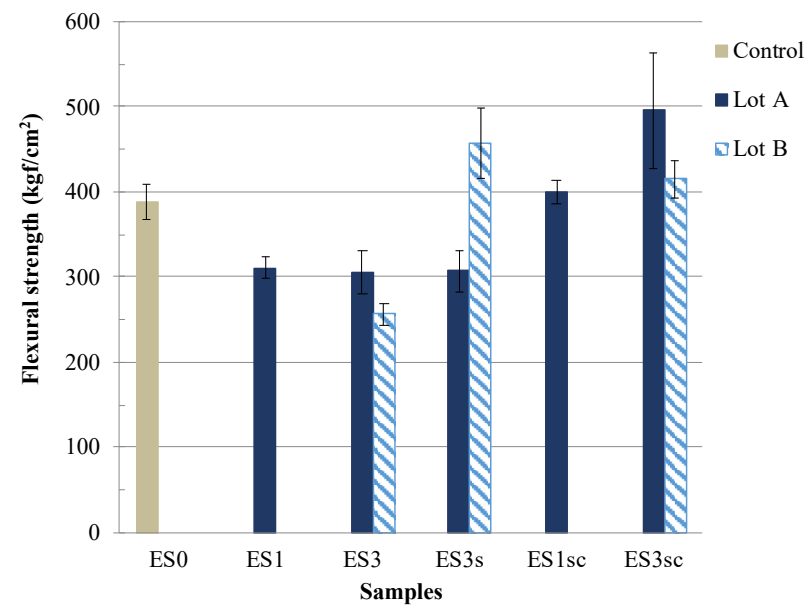

Figure 5. Effect of the ES amount and performed pre-treatment on the flexural strength of the specimens.

The colorimetric coordinates $\left(\mathrm{L}^{*} \mathrm{a}^{*} \mathrm{~b}^{*}\right)$ of all the prepared samples are shown in Table 4 together with the calculated colour difference $(\Delta \mathrm{E})$ between the specimens prepared with the two batches of ES (Lot A and Lot B). The incorporation of the ES into a stoneware ceramic paste induces brownish hues and the particle size distribution of the waste was a strong influence in the attained tinting characteristics and colour uniformity-see samples 
ES3 and ES3s (Table 4 and Figure 3). ES with a higher maximum particle size $(<425 \mu \mathrm{m})$ originates specimens (ES1 and ES3) having a nonuniform colouration (see Figure 3a). The reduction of the maximum ES particle size to $212 \mu \mathrm{m}$ promoted the development of a much more uniform hue (samples ES3s, ES1sc and ES3sc-Figure 3a). However, in both cases, the increase in the ES content promoted the development of darker stoneware pastes. Despite the benefits on the mechanical strength values, the calcination of the waste does not significantly change the colour of the samples in comparison to those incorporating non calcined ES (see samples ES3s and ES3sc-Figure 3a). The b* chromatic coordinates are very similar in all samples ranging from 11 and 17.6 and thus, only $\mathrm{L}^{*}$ and $\mathrm{a}^{*}$ chromatic coordinates were graphically represented-see Figure 6 . As expected, the control sample is the brightest one $\left(L^{*}=77\right)$ while those containing ES show darker brown hues as the incorporation level increases. Furthermore, it can be seen that the samples prepared with the ES subjected to pre-treatment II (sieved at $212 \mu \mathrm{m}$ ), ES3s, and pre-treatment III (II + calcined), ES3sc, of both ES lots, are located at the bottom right portion of the table, which confirms their chromatic similitude. Lastly, the colour difference values $(\Delta \mathrm{E})$ for the samples prepared with the two ES lots (A and B) are presented in Table 4. For the higher ES amount ( $3 \mathrm{wt} . \%$ ) the calculated $\Delta \mathrm{E}$ value is quite small if the sludge, before being added to the stoneware paste, is subjected to the pre-treatment II (milled + sieved at $212 \mu \mathrm{m}$ ) being $\Delta \mathrm{E}=1.91$ (only perceived by an experienced observer). This value is even smaller $(\Delta \mathrm{E}=0.7$; not perceived) for the samples that incorporate the ES subject to pre-treatment III (II + calcination). On the other hand, if ES that has been manually disaggregated and sieved at $425 \mu \mathrm{m}$ (pre-treatment I) is used (samples ES3), an obvious colour difference is observed between the ceramic samples prepared with the two ES lots $(\Delta \mathrm{E}=4.52)$.

Table 4. Colorimetric coordinates and colour difference $(\Delta \mathrm{E})$ of the samples.

\begin{tabular}{|c|c|c|c|c|c|c|c|}
\hline & & ES0 & ES1 & ES3 & ES3s & ES1sc & $\mathrm{ES} 3 \mathrm{sc}$ \\
\hline $\begin{array}{c}\text { Lot } \\
\text { A }\end{array}$ & $\begin{array}{c}\text { CIELab } \\
\mathrm{L}^{*} \\
\mathrm{a}^{*} \\
\mathrm{~b}^{*}\end{array}$ & $\begin{array}{c}77 \pm 2 \\
-0.59 \pm 0.04 \\
11.5 \pm 0.5\end{array}$ & $\begin{array}{c}70 \pm 3 \\
0.64 \pm 0.3 \\
13.2 \pm 0.1\end{array}$ & $\begin{array}{c}56 \pm 1 \\
2.6 \pm 0.2 \\
13 \pm 1\end{array}$ & $\begin{array}{c}45 \pm 2 \\
4.8 \pm 0.5 \\
15 \pm 1\end{array}$ & $\begin{array}{c}57 \pm 2 \\
2.8 \pm 0.4 \\
16 \pm 2\end{array}$ & $\begin{array}{c}45.6 \pm 0.6 \\
4.8 \pm 0.4 \\
15 \pm 2\end{array}$ \\
\hline $\begin{array}{l}\text { Lot } \\
\text { B }\end{array}$ & $\begin{array}{c}\text { CIELab } \\
\mathrm{L}^{*} \\
\mathrm{a}^{*} \\
\mathrm{~b}^{*} \\
\Delta \mathrm{E}\end{array}$ & - & - & $\begin{array}{c}57 \pm 1 \\
2.2 \pm 0.1 \\
17.6 \pm 0.3 \\
4.52\end{array}$ & $\begin{array}{c}44 \pm 1 \\
5.2 \pm 0.1 \\
15 \pm 1 \\
1.91\end{array}$ & - & $\begin{array}{c}45 \pm 1 \\
4.8 \pm 0.1 \\
15.3 \pm 0.4 \\
0.71\end{array}$ \\
\hline
\end{tabular}

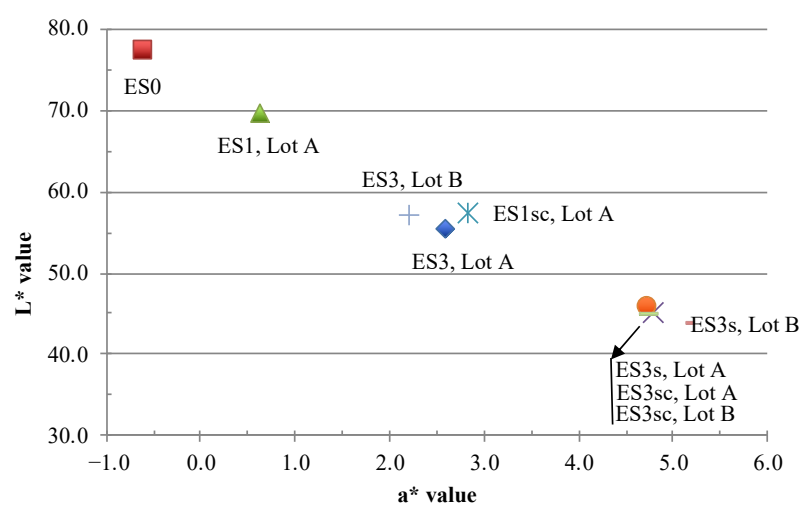

Figure 6. Graphical representation of the colorimetric coordinates $L^{*}$ (luminosity) and a* (-green, +red) of the fired samples.

The SEM micrographs and EDS images of the fractured surfaces of the specimens are shown in Figure 7. Regarding the control sample, ES0, it can be observed that a typical microstructure of a stoneware formulation is presented (a high densification degree and 
a quite homogeneous surface), with the major components being $\mathrm{Al}$ and $\mathrm{Si}$. The samples incorporating $3 \mathrm{wt} . \%$ of ES (pre-treatment I-ES3 and pre-treatment III-ES3sc) exhibit a similar microstructure; however, areas with a dissimilar aspect are observed (see the circles on the SEM images). Looking at the EDS images, it can be noticed that these regions correspond to the places where the amount of nickel and chromium is higher. Nevertheless, it can be observed that the residue is well incorporated in the matrix. The size of the ES particles depends on the applied pre-treatment: ES3sc shows smaller particles than ES3 (see Figure 7) which is in accordance with the performed pre-treatment, since in ES3sc the waste was ball milled, sieved (at $<212 \mu \mathrm{m}$ ) and calcined (pre-treatment III).

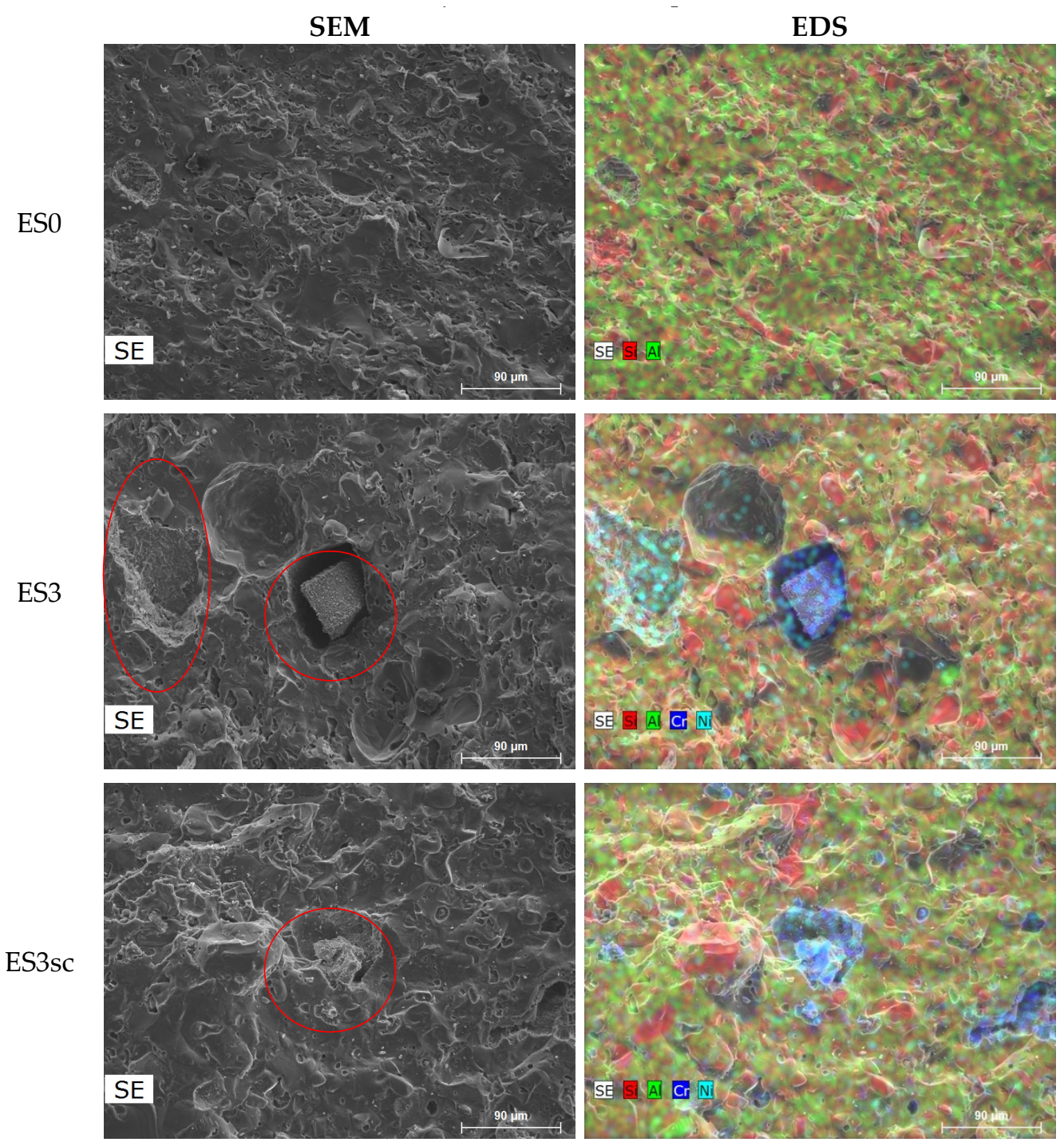

Figure 7. SEM micrographs and EDS of the fired specimens ES0, ES3 and ES3sc.

\subsection{Leaching of the Fired Products}

Table 5 presents the concentration of chromium $(\mathrm{Cr})$, nickel $(\mathrm{Ni})$, cadmium $(\mathrm{Cd})$ and lead $(\mathrm{Pb})$ leached from the stoneware cups (Figure $1 \mathrm{~b}$ ) by the acetic acid solution (4 vol.\%). The maximum permitted values of lead and cadmium are 200 and $20 \mu \mathrm{g} / \mathrm{L}$, respectively, according to the EU Ceramic Directive 84/500/EEC [37]. For chromium and nickel, the EU legislation has not defined any limits up to the present date. However, according to the Council Directive 98/83/EC [38], the maximum concentration of total chromium on drinking water for human consumption is $50 \mu \mathrm{g} / \mathrm{L}$, while for nickel the maximum concentration is $20 \mu \mathrm{g} / \mathrm{L}$. 
Table 5. Concentration of several elements leached out from the fired cups at room temperature.

\begin{tabular}{ccccc}
\hline & \multicolumn{4}{c}{ Concentration $(\boldsymbol{\mu g} / \mathrm{L})$} \\
\cline { 2 - 5 } Samples & $\begin{array}{c}\mathbf{C r} \\
\leq \mathbf{5 0}^{(\mathbf{a})}\end{array}$ & $\begin{array}{c}\mathbf{N i} \\
\mathbf{2 0}^{(\mathbf{a})}\end{array}$ & $\begin{array}{c}\mathbf{C d} \\
\mathbf{2 0}^{(\mathbf{b})}\end{array}$ & $\begin{array}{c}\mathbf{P b} \\
\mathbf{2 0 0}^{(\mathbf{b})}\end{array}$ \\
\hline ES0 & $<20$ & $<5$ & $<0.4$ & 9.9 \\
ES1 & $<20$ & 15 & $<0.4$ & 9.3 \\
ES3 & 21 & 42 & $<0.4$ & 6.7 \\
ES3s & $<20$ & $<5$ & $<0.4$ & 8.0 \\
ES1sc & $<20$ & $<5$ & $<0.4$ & 10 \\
ES3sc & $<20$ & 12 & $<0.4$ & 7.7 \\
\hline
\end{tabular}

(a) Max. values—drinking water: Council Directive 98/83/EC [38]. ${ }^{(b)}$ Max. values—mugs: EU Ceramic Directive 84/500/EEC [37].

The concentrations of lead and cadmium in the acetic acid solution are lower than 0.4 and $10 \mu \mathrm{g} / \mathrm{L}$, respectively, therefore they are significantly below the legal limits (20 and $200 \mu \mathrm{g} / \mathrm{L}$ for $\mathrm{Pb}$ and $\mathrm{Cd}$, respectively). Looking at the chromium concentration, it can be observed that, in all samples $(21 \mu \mathrm{g} / \mathrm{L}$ for the ES3 samples and $<20 \mu \mathrm{g} / \mathrm{L}$ for all the others), it is much lower than the maximum allowed for the drinking water (50 $\mu \mathrm{g} / \mathrm{L})$. A similar behaviour was observed for the Ni leaching concentrations since all the tested cups, with the exception of cup ES3, exhibit lower concentrations $(\leq 15 \mu \mathrm{g} / \mathrm{L})$ than the maximum admissible values for drinking water $(20 \mu \mathrm{g} / \mathrm{L})$. This proves that amounts up to $3 \mathrm{wt} . \%$ of pre-treated (pre-treatments II or III) ES can be used as colouring agents in stoneware bodies and endorses the benefits of the sieving $(<212 \mu \mathrm{m})$ in the immobilisation of these hazardous species. A reduction of more than $88 \%$ (from 42 to $<5 \mu \mathrm{g} / \mathrm{L}$, samples ES3 and ES3s), was observed in the leached nickel concentration. These results show that it is possible to use $\mathrm{Cr} / \mathrm{Ni}$ industrial sludge to colour stoneware bodies for tableware production, allowing a partial or total substitution of the used commercial pigments, depending on the desired colour. Consequently, a new solution for the valorisation and management of the electroplating sludge, an industrial hazardous waste, is proposed. This solution will allow ES reintroduction into the value chain of the ceramic sector as a raw material and contribute to the circular economy. Furthermore, it will allow the optimization of the available resources and reduce the consumption of virgin raw materials in the ceramic sector.

\section{Conclusions}

In the present work, an industrial $\mathrm{Cr} / \mathrm{Ni}$ electroplating sludge (ES) was incorporated in a stoneware paste, exploring the colouring potential of the waste and attempting to assure inertness/immobilization of the hazardous species.

The addition of 1 and $3 \mathrm{wt} . \%$ of ES in stoneware bodies induces minor changes in some of the samples' characteristics, namely, weight loss, shrinkage, water absorption and density. The visual appearance and the measured colour coordinates $\left(\mathrm{L}^{*} \mathrm{a}^{*} \mathrm{~b}^{*}\right)$ show that it is possible to obtain coloured stoneware products through the addition of the ES. The colour homogeneity and intensity obtained depends on the amount of the ES and its particle size. Higher ES amounts and smaller particle size give rise to a darker and more uniform colour. The amount of $\mathrm{Cr}, \mathrm{Ni}, \mathrm{Cd}$ and $\mathrm{Pb}$ leached from the semi-industrially prepared cups showed that it is possible to incorporate up to $3 \mathrm{wt} . \%$ of the ES (milled and sieved at $212 \mu \mathrm{m}$ ) since the attained values, $\mathrm{Pb}=8.0, \mathrm{Cd}<0.4, \mathrm{Cr}<20, \mathrm{Ni}<5 \mu \mathrm{g} / \mathrm{L}$, are much smaller than the ones defined by the EU Ceramic Directive 84/500/EEC and the Directive 98/83/EC, $\mathrm{Pb} \leq 200$, $\mathrm{Cd} \leq 20, \mathrm{Cr} \leq 50, \mathrm{Ni} \leq 20 \mu \mathrm{g} / \mathrm{L}$.

Summarizing, this work proved that is possible to use a hazardous waste- $\mathrm{Cr} / \mathrm{Ni}$ industrial sludge- to colour stoneware bodies for tableware, providing a new solution for the management of this waste. Therefore, sieved ES $(<212 \mu \mathrm{m})$ up to $3 \mathrm{wt} . \%$ can partially or totally substitute commercial pigments, thus allowing the reduction in the consumption of virgin raw materials and disposal costs, contributing to more sustainable consumption and 
production in the ceramic sector. Furthermore, the reintroduction of the ES, a hazardous waste generated by a distinct industrial process, into the value chain of the ceramic sector contributes not only to the circular economy, but also to achieve a real industrial symbiosis. The lack of legislation regarding the incorporation of hazardous wastes into tableware products might be a challenge to industrially implementing this solution straightaway. Consequently, efforts to classify this waste as a by-product are needed. Moreover, the monitoring of the off-gases during the sintering process of ceramic pastes containing ES should also be performed together with a life cycle assessment.

Author Contributions: Conceptualization, I.S.V. and M.P.S.; data curation, I.S.V.; funding acquisition, M.P.S.; investigation, I.S.V.; methodology, I.S.V. and J.C.; project administration, M.P.S.; supervision, C.P., J.A.L. and M.P.S.; validation, I.S.V.; writing-original draft, I.S.V.; writing-review and editing, J.C., C.P., J.A.L. and M.P.S. All authors have read and agreed to the published version of the manuscript.

Funding: This work is financed by Portugal 2020 through the European Reginal Development Fund (ERDF) in the frame of the Operational Competitiveness Internationalization Programme (POCI) in the scope of the project ECOGRES + NG - POCI-01-0247-FEDER-033853 and in the scope of the project CICECO-Aveiro Institute of Materials, UIDB/50011/2020 and UIDP/50011/2020, financed by national funds through the Portuguese Foundation for Science and Technology/MCTES.

Acknowledgments: The authors gratefully acknowledge Grohe Portugal—Componentes Sanitários, Lda for providing the $\mathrm{Cr} / \mathrm{Ni}$-rich electroplating sludge.

Conflicts of Interest: The authors declare no conflict of interest.

\section{References}

1. Zhang, Y.; Shi, P.; Chen, L.; Tang, Q. Utilization of Electroplating Sludge as Subgrade Backfill Materials: Mechanical and Environmental Risk Evaluation. Adv. Civ. Eng. 2018, 2018, 1-9. [CrossRef]

2. Magalhães, J.M.; Da Silva, J.E.; Castro, F.P.; Labrincha, J.A. Physical and chemical characterisation of metal finishing industrial wastes. J. Environ. Manag. 2005, 75, 157-166. [CrossRef]

3. Prasad, M.N.V.; de Campos Favas, P.J.; Vithanage, M.; Mohan, S.V. Industrial and Municipal Sludge: Emerging Concerns and Scope for Resource Recovery. Industrial and Municipal Sludge: Emerging Concerns and Scope for Resource Recovery; Elsevier Inc.: Oxford, UK, 2019. [CrossRef]

4. Eurostat. Generation of Waste by Waste Category, Hazardousness and NACE Rev. 2 Activity. Available online: https:/ / ec.europa. eu/eurostat/databrowser/view/ENV_WASGEN_custom_512986/default/table?lang=en (accessed on 9 December 2020).

5. Yuan, H.; Deng, L.; Cai, X.; Zheng, T.; Zhou, S.; Chen, Y.; Yuan, Y. Recycling electroplating sludge to produce sustainable electrocatalysts for the efficient conversion of carbon dioxide in a microbial electrolysis cell. Electrochim. Acta 2016, 222, 177-184. [CrossRef]

6. Tavares, C.R.G.; Franco, J.D.M. Production of concrete paving blocks (CPB) utilising electroplating residues-Evaluation of mechanical and micro-structural properties. Can. J. Chem. Eng. 2012, 90, 1092-1101. [CrossRef]

7. Gualtieri, M.L.; Mugoni, C.; Guandalini, S.; Cattini, A.; Mazzini, D.; Alboni, C.; Siligardi, C. Glass recycling in the production of low-temperature stoneware tiles. J. Clean. Prod. 2018, 197, 1531-1539. [CrossRef]

8. Vieira, C.; Monteiro, S. Incorporation of solid wastes in red ceramics: An updated review. Revista Matéria 2009, 14, 881-905. [CrossRef]

9. Hajjaji, W.; Costa, G.; Zanelli, C.; Ribeiro, M.; Seabra, M.P.; Dondi, M.; Labrincha, J. An overview of using solid wastes for pigment industry. J. Eur. Ceram. Soc. 2012, 32, 753-764. [CrossRef]

10. Andreola, N.M.; Barbieri, L.; Lancellotti, I.; Leonelli, C.; Manfredini, T. Recycling of industrial wastes in ceramic manufacturing: State of art and glass case studies. Ceram. Int. 2016, 42, 13333-13338. [CrossRef]

11. Amin, S.; Hamid, E.A.; El-Sherbiny, S.; Sibak, H.; Abadir, M. The use of sewage sludge in the production of ceramic floor tiles. HBRC J. 2018, 14, 309-315. [CrossRef]

12. Ke, S.; Wang, Y.; Pan, Z.; Ning, C.; Zheng, S. Recycling of polished tile waste as a main raw material in porcelain tiles. J. Clean. Prod. 2016, 115, 238-244. [CrossRef]

13. Andreola, F.; Barbieri, L.; Corradi, A.; Lancellotti, I.; Manfredini, T. The possibility to recycle solid residues of the municipal waste incineration into a ceramic tile body. J. Mater. Sci. 2001, 36, 4869-4873. [CrossRef]

14. Kizinievič, O.; Žurauskienè, R.; Kizinievič, V.; Žurauskas, R. Utilisation of sludge waste from water treatment for ceramic products. Constr. Build. Mater. 2013, 41, 464-473. [CrossRef]

15. Cremades, L.V.; Cusidó, J.A.; Arteaga, F. Recycling of sludge from drinking water treatment as ceramic material for the manufacture of tiles. J. Clean. Prod. 2018, 201, 1071-1080. [CrossRef] 
16. Reinosa, J.J.; Silva, A.; Rubio-Marcos, F.; Mello-Castanho, S.; Moya, J.; Fernández, J. High chemical stability of stoneware tiles containing waste metals. J. Eur. Ceram. Soc. 2010, 30, 2997-3004. [CrossRef]

17. Bocanegra, J.J.C.; Mora, E.E.; González, G.I.C. Galvanic sludges: Effectiveness of red clay ceramics in the retention of heavy metals and effects on their technical properties. Environ. Technol. Innov. 2019, 16, 100459. [CrossRef]

18. Ewais, E.M.; Besisa, N.H.; Ahmed, A. Aluminum titanate based ceramics from aluminum sludge waste. Ceram. Int. 2017, 43, 10277-10287. [CrossRef]

19. Santos, P.; Martins, C.; Júlio, E. Enhancement of the thermal performance of perforated clay brick walls through the addition of industrial nano-crystalline aluminium sludge. Constr. Build. Mater. 2015, 101, 227-238. [CrossRef]

20. Tucci, A.; Rambaldi, E.; Esposito, L. Use of scrap glass as raw material for porcelain stoneware tiles. Adv. Appl. Ceram. 2006, 105, 40-45. [CrossRef]

21. Silva, R.V.; de Brito, J.; Lye, C.Q.; Dhir, R.K. The role of glass waste in the production of ceramic-based products and other applications: A review. J. Clean. Prod. 2017, 167, 346-364. [CrossRef]

22. Vieira, C.; Andrade, P.; Maciel, G.; Vernilli, F.; Monteiro, S. Incorporation of fine steel sludge waste into red ceramic. Mater. Sci. Eng. A 2006, 427, 142-147. [CrossRef]

23. Liu, T.; Zhang, J.; Wu, J.; Liu, J.; Li, C.; Ning, T.; Luo, Z.; Zhou, X.; Yang, Q.; Lu, A. The utilization of electrical insulators waste and red mud for fabrication of partially vitrified ceramic materials with high porosity and high strength. J. Clean. Prod. 2019, 223, 790-800. [CrossRef]

24. He, H.; Yue, Q.; Qi, Y.; Gao, B.; Zhao, Y.; Yu, H.; Li, J.; Li, Q.; Wang, Y. The effect of incorporation of red mud on the properties of clay ceramic bodies. Appl. Clay Sci. 2012, 70, 67-73. [CrossRef]

25. Silva, T.H.; Castro, A.C.M.; Neto, F.C.V.; Soares, M.M.N.S.; De Resende, D.S.; Bezerra, A.C.S. Recycling ceramic waste as a raw material in sanitary ware production. Cerâmica 2019, 65, 426-431. [CrossRef]

26. Karaahmet, O.; Cicek, B. Waste recycling of cathode ray tube glass through industrial production of transparent ceramic frits. J. Air Waste Manag. Assoc. 2019, 69, 1258-1266. [CrossRef] [PubMed]

27. Carneiro, J.; Tobaldi, D.; Capela, M.; Novais, R.; Seabra, M.; Labrincha, J. Synthesis of ceramic pigments from industrial wastes: Red mud and electroplating sludge. Waste Manag. 2018, 80, 371-378. [CrossRef]

28. Magalhães, J.M.; Silva, J.E.; Castro, F.P.; Labrincha, J.A. Role of the mixing conditions and composition of galvanic sludges on the inertization process in clay-based ceramics. J. Hazard. Mater. 2004, 106, 169-176. [CrossRef] [PubMed]

29. Magalhães, J.M.; Silva, J.E.; Castro, F.P.; Labrincha, J.A. Kinetic study of the immobilization of galvanic sludge in clay-based matrix. J. Hazard. Mater. 2005, 121, 69-78. [CrossRef]

30. Vitkalova, I.; Torlova, A.; Pikalov, E.; Selivanov, O. Development of environmentally safe acid-resistant ceramics using heavy metals containing waste. MATEC Web Conf. 2018, 193, 03035. [CrossRef]

31. Grand View Research. Available online: https://www.grandviewresearch.com/industry-analysis/tableware-market (accessed on 21 April 2020).

32. European Commission. A European Green Deal. Available online: https://ec.europa.eu/info/strategy/priorities-2019-2024/ european-green-deal_en (accessed on 21 April 2020).

33. Allied Market Research. Available online: https://www.alliedmarketresearch.com/eco-friendly-tiles-market, (accessed on 2 May 2020).

34. BSI Standards Publication, EN:1217 B Materials and Articles in Contact with Foodstuffs. In Test Methods for Water Absorption of Ceramic Articles; BSI: London, UK, 1998; p. 10.

35. Commission Internationale d'Eclairage. Recommendations on Uniform Colour Spaces, Colour Difference Equations, Psychometrice Colour Terms. J. Oral Rehabil. 1978. [CrossRef]

36. Mokrzycki, W.S.; Tatol, M. Colour difference Delta-E. A survey. Mach. Graph. Vis. 2011, 20, $383-411$.

37. Council of the European Union. Council Directive 84/500/EEC of 15 October 1984 on the Approximation of the Laws of the Member States Relating to Ceramic Articles Intended to Come Into Contact with Foodstuffs. Off. J. Eur. Communities 2005. Available online: https:/ / eur-lex.europa.eu/legal-content/EN/ALL/?uri=CELEX\%3A31984L0500 (accessed on 21 April 2020).

38. European Parliament and Council. Council Directive 98/83/EC of 3 November 1998 on the Quality of Water Intended for Human Consumption (OJ L 330 05.12.1998). Documents in European Community Environmental Law. 2015. Available online: https:/ / eur-lex.europa.eu/legal-content/EN/TXT/?uri=celex\%3A31998L0083 (accessed on 21 April 2020). 